\title{
FORMATION OF PROFESSIONAL MOTIVATION OF STUDENTS OF INSTITUTIONS OF HIGHER EDUCATION TO SELF-REALIZATION IN LIFE
}

\begin{abstract}
The article reveals the issues of professional motivation of graduates of institutions of higher education to self-realization in life, the need for interaction between employers and institutions of higher education, which trains specialists for a particular sphere and not always cope with providing them with the knowledge that affects the development of competencies necessary for the performance of official responsibilities at a particular place of work. The emphasis has been placed on the importance of vocational guidance measures for professional motivation, interaction between employers and institutions of higher education. The importance of acquiring professional competence by students for professional self-realization in the future, application of innovative technologies in their teaching, involvement in situational modeling and project development have been highlighted. It has been emphasized that the component of the student's educational motivation can be orientation to international relations, the state's course on academic mobility.

The publication outlines the positions of modern scholars on the difficulties of self-realization in the professional sphere, which are influenced by external and internal factors. It has been noted that in the structure of readiness for professional activity, there are motivational, emotional-volitional, orientational components. It has been emphasized that insufficient level of professional training of graduates is explained by the emphasis on their attention only on the material and social advantages of the chosen profession. The focus is on the need for youth to find appropriate bases of practice that will satisfy the institution of higher education, students and employers. It has been noted that an important role for the employer plays a potential employee's possession with new information technologies. It has been explained that today it is important to rethink the role of scientific designing, counseling, directing students to self-realization and scientific guidance from teachers as mentors, tutors. It has been emphasized that the modernization of the educational branch focuses on the recognition of the diploma of the graduate of the institutions of higher education as evidence of real professional qualifications.

Keywords: professional motivation, self-realization, occupational orientation measures, professional competence, innovative technologies, international relations, academic mobility.
\end{abstract}

Formulation of the problem. The continuation of social, economic, political transformations in society is a transformation that extends to the educational branch, as it significantly influences the intensity of the state's development. In these conditions, pedagogical science requires radical changes taking into account domestic and foreign trends of development. Taking into account Ukraine's integration into the European educational space, we must focus on educating young people from the position of humanity, according to which each person develops, realizing his or her own potential. The implementation of creative resources is most effective in the case of its active interaction with other people while preserving their own identity. The ability to productive interaction, which is carried out in the interests of both the individual and society as a whole, manifests itself in the professional activity.

This interaction takes place between employers and higher education institutions that train specialists for a particular field and do not always cope with providing them with the knowledge that affects the development of the competencies necessary for the performance of official duties at a specific place of work. For the same reason, graduates often refuse to work according to their qualification, considering the conditions of work and wages, which often do not correspond to their perceptions of their realization in the professional field.

In today's conditions of development of professional knowledge, the development of a positive attitude towards the future profession is important for young people. The development of this problem is gaining importance in pedagogical theory, in particular, in distinguishing the most important aspects of vocational guidance work both in school and in the process of vocational training.

In order to raise the level of understanding about the specialty chosen for entry by young people, it is necessary to carry out vocational guidance measures: holding nationwide actions, seminars, exhibitions, round tables, training seminars; to form professional motivation, explaining to them what they will have to face in life, carrying out the activity according to the chosen specialty.

Future specialists need to constantly develop and refine themselves so that the employer will be confident in their competence and professionalism, and institutions of higher education, in turn, should focus on the training motivation of students and the quality of their training, taking into account the requirements of the labor market [5].

The objective of the publication is to reveal the issue of professional motivation of graduates of higher education institutions to self-realization in life, in order to realize the importance of a well-balanced approach to the choice of sphere of application of knowledge, skills and abilities acquired in institutions of higher education

Analysis of recent research and publications. Today's life requires from young people to focus on high professionalism, teamwork, speed and responsibility in decision making, the ability to express themselves and skill in building interpersonal relationships, awareness of the need for constant professional growth, replenishment and knowledge deepening [6]. This induces scientific and pedagogical workers to form the professional motivation of students while studying in the institutions of higher education.

The problem of studying the peculiarities of the formation of professional motivation of a person is devoted to a number of works of domestic and foreign scientists, among which we find the following names: I.R. Abramova, R.S. Vaisman, SA Gaponova, N.E. Gorska, T.V. Ivanova, Ye.P. Ilyin V.A. Karnaukhov G.A. Muhina, A. Pechnikova, L.V. Popova, L.D. Stolyarenko, R.I. Tsvetkova and others. The attention to study of the regularities of the formation of professionalism, individual style of activity is paid attention by B.G. Ananiev, A.A. Bodalev, A.A. Derkach, B.F. Lomov, B.A. Klimov, K.K. Platonov, V. D. Shadrikov, R. L. Krichevsky, L.D. Kudryashova, V.I. Lebedev, A.V. Filippov, V.G. Zazikin, N.V. Kuzmin, A.A. Rean and others.

Modern scholars are convinced that the difficulties of selfrealization in the professional sphere depend on external and internal factors. Among them, an important place belongs to the personal factor, as such, which includes a number of individual characteristics of the individual. Professional self-realization is considered as a characteristic of all life path, influenced by changes in the socio-economic state of the country, which causes the transformation of the motivational peculiarities of professional self-realization of the individual.

Successful professional self-realization in human life is promoted by professional competence, readiness to perform a certain type of work that enables its adaptation to the pro- 
fession. In the structure of readiness for professional activity, scientists mostly distinguish motivational, emotional-volitional, orientational components.

The motivational component, in their beliefs, includes professional settings, interests, and the desire to be engaged in work. The stability, depth and breadth of professional interests and ideals are determined by orientation. The degree of formation of professional interest determines the nature of the future specialist's work on himself in order to use his abilities and skills. The motivational component brings the rationale for the goals of the activity, due to the emotional and volitional state of the individual. Emotionalvolitional component consists of feeling, emotional susceptibility, purposefulness, self-control, persistence, initiative, determination, independence, self-criticism, self-control and others. The orientation component includes value orientations of the individual: beliefs, views, principles and readiness to act in practical situations. The professional beliefs of a specialist are an important part of his readiness for professional activity, which includes professional education, although not only it determines the overall success of the activity. The significant thing is professional ethics with its moral standards, assessment and self-esteem, control and self-control, and so on.

Educational motivation depends on a number of factors, including the institution of higher education and the peculiarities of organization of educational process in it; personal and professional qualities of teachers; the specifics of the disciplines; individual characteristics of students, among which intellectual flexibility, consistency, focus on the result.

The formation of professional competences depends on the student's motivation and is manifested through behavior. The so-called competence according to J. Raven involves: motivation and ability to plunge into activity (to take initiative, take responsibility, analyze the work of organizations or political systems); readiness to plunge into subjectively significant actions (to strive to influence what is happening in the organization, where a person works or on the direction of the movement of society); the ability to help the climate support and encourage those who try to innovate or seek ways to work more effectively; understanding of how the organization and society function, perceiving their own role and the role of other people in organization and society; adequacy of the concept of management-related organizations (risk, efficiency, leadership, responsibility, accountability, communication, equality, participation, welfare and democracy [4].

Research presentation. Formation of professional motivation of students for self-realization in the future takes place under the condition of active position of scientific and pedagogical workers who provide high-quality knowledge of theories, laws, concepts in a way that the future specialist could design them into practical activities that will facilitate increasing of professional potential.

The quality of the process of professional training of students is influenced by their motives related to the interest in a particular profession, the desire to learn a new one and practically realize the acquired knowledge. Insufficient level of professional training for graduates of higher education institutions is due to their emphasis on the material and social benefits of the chosen profession, therefore we can state the fact that an important factor of satisfaction with the profession in the future is the correct identification of the professional interests of young people prior to entering the higher education institutions, awareness of their professional inclinations and understanding of the content of future professional activities.

Today there is a tough competition at the labor market, as employers seek to attract graduates of higher education institutions to work with modern knowledge and practical skills, and therefore often offer students the opportunity to practice at a particular place of work in order to accelerate their adaptation to it. An important role in this process belongs to the magistracy. It provides the training of students in specific fields with the possible deepening of theoretical knowledge from self-selected disciplines and the passing of industrial practice. Among applicants for higher education, there is the opinion that they need to be affiliated as interns to a particular institution for the entire period of study at the magistracy, although this raises many questions of financial order in connection with the need to pay remuneration to practice. Hence it is necessary to look for future relevant bases for practice that will satisfy the institution of higher education, students and employers.

Usually, most graduate students are busy with their future employment. They listen to the advice of experienced teachers, especially those who invite specialists according to the qualification acquired by students. These teachers may be former graduates of the higher education institutions, who can motivate students to study specific disciplines, because knowledge of them can contribute to the faster doing specific work. Communicating with them helps to make the young people aware of the need to acquire certain competencies. It can change the student's presentation about the specifics of work in a particular field, the possibilities of their professional growth. Formation of professional competences for future specialists depends on their teachers rethinking of their experience and purpose of their activity. It should take place in each professionally-oriented discipline, and this should be facilitated not only by the experience of the teacher, but also by the student's creative attitude to the solution of the tasks, especially when performing independent work, which can be based on substantiation of extraordinary situations in the future professional field, participation in role and business games etc. Independent work motivates students not only to master the content of a particular discipline, but also to develop the ability to take responsibility, find constructive solutions and exit problematic situations, forming perseverance, purposefulness, etc. [1]. It contributes to the deepening and expansion of knowledge, the mastery of the methods of the process of knowledge, the development of cognitive abilities. Independent work contributes to the development of communicative skills, the ability to work not only individually, but also in groups, and from here to carry out tasks both individually and collectively, which is important for the formation of professional competencies.

In the professional motivation of students, the teacher using of innovative technologies (use of electronic educational resources, interactive whiteboards, unique systems of testing and knowledge control, video conferencing, etc.), situation modeling, project development plays an important role in the process of learning.

In this context, the study of the labor market, an analysis of trends in the development of various subject areas is important for the purpose of gathering information for the teaching disciplines. Gradual improvement of online training courses is necessary, transforming the usual learning process into more mobile, in which teachers and students can exchange information in all conditions and at any time. Curricula, programs, and the content of each discipline should be directed to the formation of professional competencies of students.

It is important for an employer that a potential employee can use new information technologies, as well as the scientific-educational workers of the institutions of higher education must be not only informed about the software used by the employers, but also teach students to work with them. 
Today it is important to rethink the role of scientific design, counseling, and orientation of students in the process of learning to self-realization. It is desirable to support scientific leadership of teachers as mentors, tutors. As a rule, this is not an easy matter, because scientific-pedagogical workers should give many classes, engage in the preparation of educational publications, scientific publications, conduct public activities, etc. As teachers possess tools for influencing consciousness, emotions, human values, their behavior in the family, the team and are able to pass on this experience to students, we can be certain that many of the problems that exist today in society will be professionally solved.

In the student's age, the need for self-actualization is extremely relevant, so young people need the help of skilled professionals in finding activities in which they could succeed, feel pleasure and inner comfort. It would be useful to organize for them training and master classes on interviewing, finding places of work and practice, internships, writing a resume, etc.

Creation of optimal conditions for the student's self-realization in an institution of higher education, orientation of the strategy of higher education to the humanistic paradigm contribute to the readiness to search for the future sphere of activity, the disclosure of own potential, and the enrichment of student's spirituality.

Today, the component of student's educational motivation can be orientation towards international relations. "The Law of Ukraine about Education" (Article 82. International Cooperation in the System of Education) states that "Establishments of education, scientific, scientific-production institutions of the educational system, state educational management bodies have the right to conclude cooperation agreements, establish direct links with educational establishments, enterprises, institutions, organizations, scientific institutions of the education system of foreign countries, international enterprises, institutions, organizations, foundations, etc. "[3]. It stimulates young people to get jobs that will help them to be realized not only in their country but also abroad. In addition, the professional growth of higher education graduates promotes a course on academic mobility, as referred to in the above-mentioned Law (Article 84 International Academic Mobility), and points to the need for the state to create the conditions for "the development of joint educational and scientific programs with foreign educational institutions, scientific institutions and organizations" and its assistance in "participation in the programs of bilateral and multilateral international exchange of education, pedagogical, scientific, pedagogical and scientific workers "[3].
Conclusions. Doing the professional motivation of graduates of institutions of higher education, scientific-pedagogical staff should take into account the expectations of consumers of educational services, the dynamics of changes in social needs, and promote the development of partnerships between government bodies, employers and the public.

Today it is important to realize that the specialist diploma, as sad in the Law of Ukraine "About Higher Education" (2014), received within the educational institutions, is a signal to the employer as to what position the individual claims to enter the labor market [2]. The modernization of the educational industry focuses on the recognition of it as evidence of real professional qualifications, and not as a formal confirmation of the level of personality education.

References

1. Buryak V.K. Keruvannya samostiynoyu robotoyu studentiv / V.K.Buryak // Vyshcha shkola. - 2001. - № 4-5. - S.48-52.

2. Zakon Ukrayiny "Pro vyshchu osvitu" vid 01.07.2014 № 1556-VII [Elektronnyy resurs]. - Rezhym dostupu: http://zakon4.rada.gov.ua/laws/ show/1556-18.

3. Zakon Ukrayiny "Pro osvitu". Vidomosti Verkhovnoyi Rady (VVR). 2017, № 38-39, st.380.

4. Raven Dzh. Kompetentnost' v sovremennom obshchestve: vyyavlenye, razvytye y realyzatsyya: [monohrafiya] / Dzhon Raven; [per. s anhl.]. - M.: Kohyto-Tsentr, 2002. $396 \mathrm{~s}$

5. Shul'ha L.V. Pidvyshchennya yakosti universytet-s'koyi osvity: profesiyna ta praktychna pidhotovka fakhivtsiv / Shul'ha L.V., Brazhnyk L.V., Vakulenko YU.V. I/ Naukovi pratsi Poltavs'koyi derzhavnoyi ahrarnoyi akademiyi. Vyp. 1 (6). T. 2. - Poltava: PDAA, 2013. - S. 335-338.

6. Yasynevych S. Rol' informatsiynykh tekhnolohiy u formuvanni hromadyans'koho suspil'stva [Elektronnyy resurs]/ Yasynevych S.//Publichne administruvannya: teoriya ta praktyka [Elektron. zb. nauk. pr. / red. S.M. Ser'ohin ta in.]. - D.: DRIDU NADU, 2016. Vyp. 1(15). Rezhym dostupu: www.dridu.dp.ua

\section{Список використаних джерел}

1. Буряк В.К. Керування самостійною роботою студентів / В.К.Буряк // Вища школа. - 2001. - № 4-5. - С.48-52.

2. Закон України "Про вищу освіту" від 01.07.2014 № 1556-VII [Електронний ресурс]. - Режим доступу: http://zakon4.rada.gov.ua/laws/ show/1556-18

3. Закон України "Про освіту". Відомості Верховної Ради (ВВР). - 2017, № 38-39, ст. 380 .

4. Равен Дж. Компетентность в современном обществе: выявление, развитие и реализация: [монографія] / Джон Равен; [пер. с англ.]. - М. Когито-Центр, 2002 - 396 с.

5. Шульга Л.В. Підвищення якості університетської освіти: професійна та практична підготовка фахівців / Шульга Л.В., Бражник Л.В., Вакуленко Ю.В. // Наукові праці Полтавської державної аграрної академії. Вип. 1 (6). Т. 2. - Полтава: ПДАА, 2013. - С. 335-338.

6. Ясиневич С. Роль інформаційних технологій у формуванні громадянського суспільства [Електронний ресурс]/ Ясиневич С.//Публічне адміністрування: теорія та практика [Електрон. зб. наук. пр./ред. С.М. Серьогін та ін.]. - Д.: ДРІДУ НАДУ, 2016. Вип. 1(15). Режим доступу: www.dridu.dp.ua.

Надійшла до редколегї̈ 09.03.19

А. Марушкевич, д-р пед. наук, проф.

Київський національний університет імені Тараса Шевченка, Київ, Україна

\section{ФОРМУВАННЯ ПРОФЕСІЙНОЇ МОТИВАЦІЇ СТУДЕНТІВ ЗАКЛАДІВ ВИЩОЇ ОСВІТИ ДО САМОРЕАЛІЗАЦІЇ В ЖИТТЄДІЯЛЬНОСТІ}

Розкривається питання професійної мотивації випускників закладів вищої освіти до самореалізації в життєдіяльності, необхідності взаємодії між роботодавцями і закладами вищої освіти, які готують фахівців для конкретної сфери і не завжди справляються із забезпеченням їх тими знаннями, котрі впливають на вироблення компетентностей, необхідних для виконання посадових обов'язків на конкретному місиі роботи Акцентується увага на значенні у формуванні професійної мотивації профорієнтаційних заходів, взаємодії між роботодавцями і зВО. Висвітлюється значення набуття студентами професійної компетентності для професійної самореалізації у майбутньому, застосування у їх навчанні інноваційних технологій, залучення до моделювання ситуацій та розробки проектів. Наголошується, що складовою навчальної мотивації студентів може бути орієнтація на міжнародні зв'язки, взятий у державі курс на академічну мобільність.

У публікації вказано позичії сучасних учених щодо труднощів самореалізації у професійній сфері, на які впливають зовнішні внутрішні фактори. Зазначено, що в структурі готовності до професійної діяльності вчені здебільшого виділяють мотиваційний, емоційно-вольовий, орієнтаційний компоненти. Підкреслено, що недостатній рівень професійної підготовки випускників пояснюється акцентуванням їх уваги лише на матеріальних і соціальних перевагах обраної професії. Зорієнтовано на необхідність пошуку для молоді відповідних баз практики, які задовольнять заклад вищої освіти, самих студентів та роботодавців. Зауважено, що для роботодавця важливу роль відіграє ступінь володіння потенційним співробітником новими інформаційними технологіями. Пояснено, що на сьогодні важливим є переосмислення ролі наукового проектування, консультування, спрямування студентів на самореалізацію і наукове керівництво з боку викладачів як наставників, тьюторів. Наголошено, що модернізація освітньої галузі орієнтує на усвідомлення диплома випускника ЗВО як свідчення справжньої професійної кваліфікації.

Ключові слова: професійна мотивація, самореалізація, профорієнтаційні заходи, професійна компетентність, інноваційні технології, міжнародні зв'язки, академічна мобільність. 